\title{
Irishness, Female Subjectivity, Domestic Relation, and Landscape as manifested in Carr's The Mai \& Ariel
}

\author{
Dr. Haitham Mohamed Yehia Abd Elrahman \\ PH.D. in English Literature, \\ Faculty of Arts, Mansoura University
}

\begin{abstract}
:
This research aims at discussing the depiction of liminal space in the theater of Marina Carr, especially in The Mai (1994) and Ariel (2002), as an approach for presenting and analyzing the tension rooted in some issues pertinent to themes of gender, family, and identity. It aims at discussing the importance of the landscape in her drama as a primary setting and a dominant feature symbolizing the Irish folklore. Furthermore, it discusses how Carr interested in creating a conflicted space between binary oppositions that have characterized the prevailing ways of thinking and writing about Ireland in the nineteenth century reaching to the transition in the middle and until the end of the twentieth century. In conclusion, the two plays under study illustrate how the concept of liminality is employed as a way for the protagonists to re-imagine their real conditions. They allow readers to re-imagine the rapid change of Irish culture and community, which displays a postmodern self-awareness in the plays' multiple meta-theatrical elements.

Keywords: Liminal space, Gender, Family, Identity, Midlands, Irish folklore, Binary oppositions, and Postmodern self-awareness.
\end{abstract}




\section{الهوية الأيرلندية والذاتية الأنثوية والعلاقات الأسرية والمناظر} الطبيعية كما تبلت في هسرحيتي زا هاي وآريل لمارينا كار

$$
\text { د. هيثم تحمد يحيي عبدالرحمن }
$$

دكتوراة في الأدب الإنجليزي، كلية الآداب، جامعة المنصورة

\section{هلغص البمث}

يهدف هذا البحث إلى مناقثة تصوير الفضاء الحدي في مسرح مارينا كار، بثكل

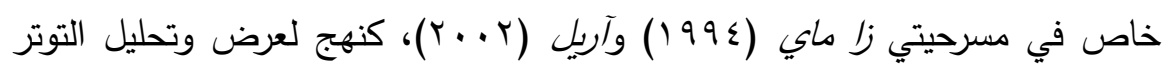
المتأصل في بعض القضايا ذات الصلة بموضوعات الهوية والجنس والأسرة. كما يهدف إلى مناقشة أهمية المناظر الطبيعية في دراما كار كإطار أساسي وميزة مهيمنة ترمز إلى إلى الفولكلور الأيرلندي. علاوة على ذلك، يناقش البحث اهتمام كار بخلق مساحة متضاربة

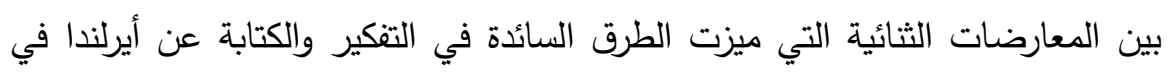
القرن التاسع عشر وصولاً إلى مرحلة التحول في منتصف وحتى نهاية القرن العشرين. كما يتاول البحث استخدام كار للفولكلور المحلي ليس فقط لتأسيس تاريخ المناظر الطبيعية ولكن أيضًا لعكس عالمية نضالات بطلاتها. أخيراً، توضح المسرحتان قيد الدراسة كيفية استخدام مفهوم اللامحدودة كطريقة لبطلتين هاتان المسرحيتان في إعادة

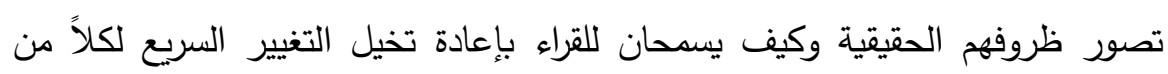

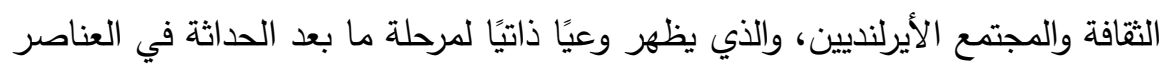
المتعددة للمسرحيات.

الكلمات المفتاحية: الفضاء الحدي، الهوية، الجنس، الأسرة، المناظر الطبيعية. 
Irishness, Female Subjectivity, Domestic Relation, and Landscape as manifested in Carr's The Mai \& Ariel

Dr. Haitham Mohamed Yehia Abd Elrahman

مجلة وادي النيل للاراسات والبحوث الإنسانية والاجتماعية والتربوية (مجلة علمية محكمة)

Irishness, Female Subjectivity, Domestic Relation, and Landscape as manifested in Carr's The Mai \& Ariel

\section{Introduction}

The seventies and eighties of the past century are considered significant decades, which presented several eminent Irish playwrights during the postmodern era. Carr is one of the contemporary Irish playwrights who emerged during those decades; she is really interested in exploring the national identity of Ireland via her plays, which constitute significant contributions to the Irish dramatic movement throughout both the last century and the current twenty-first. As Carr was born and brought up near Tullamore - County Offaly - in Ireland's Midlands, she has acquired a deep self-consciousness placing her in a position of the leading playwrights in the postmodern phase and Irish drama as well. Hence, Carr receives a great deal of controversy pertaining to her works.

In an interview with Marina Carr, Novillo-Corvalan inquired about her upbringing in the Midlands and how the countryside had a great impact on the formation of her drama. In this vein, Carr asserts that Irish Midlands had really a massive influence on her as she points out:

I grew up in a place called Gortnamona, which means 'field of the bog', for the first 11 years, and then moved a half mile down the road to a place called Pallas Lake. Our house was on the shore of the lake. There were swans, there were bulls, there were dragonflies, there were fishermen. My sister and I spent long summer evenings sitting on an old Oak tree looking out at the lake, laughing our heads off at anything, everything, nothing. The winters were cold, sometimes the lake froze. I went to my mother's school along with my brothers and sister...When the weather was fine, she would let us play for hours 
(ISSN : 2536 - 9555)

outside...it was a good childhood, free and fairly wild. (145)

Carr employs the landscape of the Midlands in order to create an area, which accommodates a kind of Irish heart of darkness, and she uses geography through her drama on two levels: firstly, to parallel emotional states in the characters. Secondly, to open Ireland out into a metonym for the world as the vulnerable home and shelter of the human race; as Claudia Harris stated, Carr's passageway into an ancient new imaginative world is the Irish Midlands (Leeney 510). Therefore, the setting of these works of drama is considered as one of the characters in her plays; Carr indicated this clearly when she said in an interview referenced by Hillary Campos, "I've always thought that landscape was another character in the work, and if you can get it right, it'll resonate and enrich the overall piece" (qtd. in Campos 2).

Leeney states that Carr who is best-known as an Irish woman playwright has exploited her gender for marketing her works, and she undoubtedly burdened the responsibility of representing women's issues and their experiences on many levels. While, the feminist readings and understandings of Carr's theater reveal gender deficit in Irish theatrical traditions where women are represented rather than representing; at times, Carr, through her plays, expresses the females' anger towards the nation. However, Carr's canvas is larger than only expressing women's concerns and their issues; theater of Marina Carr, in the context of postmodern playwriting, refers in a playful and mischievous style to the classical Greek and the Irish canons as well as recalling some images derived from Shakespeare, legend and Irish myth (510).

In addition, theater of Carr apparently concentrates on the family and female subjectivity, especially renegotiating limiting cultural notions of woman as an idealized Mother-figure and symbol of nation as well as discussing issues of sexuality, gender, and body. These works of drama have been afforded an agency of female subjectivity via their protagonists' access to sites of imaginative "otherness", whether through storytelling, folktale, poetic expression, or communicating with nature and dead, 
Irishness, Female Subjectivity, Domestic Relation, and Landscape as manifested in Carr's The Mai \& Ariel

Dr. Haitham Mohamed Yehia Abd Elrahman

مجلة وادي التيل للاراسات والبحوث الإنسانية والاجتماعية والتربوية (مجلة علمية محكمة)

offering a powerful means which articulate the ontological immobility of their patriarchal relegation versus the limited roles of daughter, wife, and mother (Sihra 133). Hence, it is evident that Carr's theater, within the canonical legacy of mostly male Irish playwrights, has generated a special tradition noticeably focused around mutually dependent male-pairings and offered representations challenging the traditional depictions of identity and culture with particularly a great respect to issues of woman, motherhood, and the family.

Based on what have been mentioned above, this research mainly will shed the light on the depiction of liminal space in the theater of Marina Carr, especially in The Mai (1994) and Ariel (2002), as an approach for presenting and analyzing the tension rooted in some issues pertinent to themes of gender, family, and identity. Furthermore, it aims at discussing the importance of the landscape in Carr's drama as a primary setting and a dominant feature which symbolizes the Irish folklore; it also examines her representations of the Irish Midlands in terms of their geography in the center of Ireland with their bogs, which are neither land nor water.

As Parrott explains, Carr's works of drama under study concentrate chronologically on the development of liminality in relation to the issues of landscape, gender, and identity of Ireland. She is also interested in creating a conflicted space between binary oppositions that have characterized the prevailing ways of thinking and writing about Ireland in the nineteenth century reaching to the transition in the middle and until the end of the twentieth century. Likewise, Carr pays a great attention for exploring the lives of those geographically and socially existing between the binary oppositions rather than deconstructing the binary opposites themselves (3).

Therefore, in Carr's theater and more specifically the two plays under research, various methods through which Ireland's vision is constructed are explored; these methods include: gender, via concentration on women's roles in contemporary Irish society 
(ISSN : 2536 - 9555)

and representations of female protagonists rejecting to live within the confines of the domestic realm; Landscape, in which most of Carr's works of drama have been set, in the middle of Ireland, outside the binary poles of north, south, east and west; Irish identity, through presenting characters, who do not share the values of the surrounding communities which they live in (Parrott 4), and, lastly, Family, which has been represented a site of contestation, disunity, and violation through the persistent exploration to femininity as well as issues of gender and sex which decisively revolt against the monological nationalist, anti-feminist, colonial, and postcolonial issues of both identity and history. Moreover, the primary function of the family, which has been stated in the enshrined Article No. 41 of Ireland's Constitution, is to determine and maintain strictly codified gender roles for the sake of landownership protection and inheritance practices (Sihra 134).

In this respect, Bacik indicates that, "Family is granted a unique status in Article 41 of the [Irish] Constitution as the basic unit upon which society is founded. The family therefore possessed an extraordinarily high level of constitutional recognition and protection" (67). While, Sihra views that the position and role of the Irish women have been constitutionally determined in the late thirties of the twentieth century through the understanding for the Family Article. She also states that the definition of the woman's duties has been precisely determined by the mother's role in the Irish Constitution, which basically views woman as an entity whose major and social role is to give birth to legitimate heirs as well as managing the domestic sphere (134).

Carr revolts in these contemporary representations of woman, family, and home against the patriarchal ideologies of the Catholic Church and the Constitution of Ireland, which both imprisoned and fixed the representations of woman in the twentieth century (Sihra 135). Whereas, the validation of the mutuallydependent and interchangeable conception of the Irish womanmother figure is actually contained within the domestic sphere of the family and the home, which is stated in the Irish Constitution as the clause No. 2.2 of the Family Article No. 41 says, "The State 
Irishness, Female Subjectivity, Domestic Relation, and Landscape as manifested in Carr's The Mai \& Ariel

Dr. Haitham Mohamed Yehia Abd Elrahman

مجلة وادي التيل للاراسات والبحوث الإنسانية والاجتماعية والتربوية (مجلة علمية محكمة)

shall, therefore, endeavor to ensure that mothers shall not be obliged by economic necessity to engage in labor to the neglect of their duties in the home."

However, the feminist groups considered gender role, in the above-mentioned Article, is an attempt to limit public opportunities for women, and they viewed it as a severe setback for the feminist movements at the beginning of the twentieth century (Breda Gray and Louise Ryan 129). Hence, this controversy is really embodied in Carr's female characters where those protagonists feel more restricted by the actions and values of their ancestors as well as the social norms of their local communities, and the limitations of their roles as only being wives and mothers. Thus, those women feel more rested at homes surrounded by landscapes, as they are not inherently domestic and such places provide them both great solace and much freedom. In this vein, Butler argues that:

.... there is, latent in the personal is political formulation of feminist theory, a supposition that the life-world of gender relations is constituted, at least partially, through the concrete and historically mediated acts of individuals. Considering that "the" body is invariably transformed into his body or her body, the body is only known through its gendered appearance...... the body becomes its gender through a series of acts which are renewed, revised, and consolidated through time. From a feminist point of view, one might try to reconceive the gendered body as the legacy of sedimented acts rather than a predetermined or foreclosed structure, essence or fact, whether natural, cultural, and linguistic. (523)

Ultimately, Carr's female protagonists are rejected by their communities due to their great preference for the landscape over the socially and physically constructed milieu of the 'home', and they turn to suicide as a sole solution in order to cope with these circumstances. As Parrott illustrates, landscape constitutes a key position in Carr's works of drama where the setting of Midlands 
(ISSN : 2536 - 9555)

employs somehow between the archetypal landscapes of Synge's West and O' Casey's East; it is also depicted between the religious and political tensions of the North and South of Ireland (5).

The employment of the boggy territory of the Midlands in Carr's The Mai and Ariel constitutes a necessity for many reasons; the most important one is that bogs have liminal qualities because they are neither solid ground nor flowing water. In addition, these bogs lie somewhere between spongy territories appearing barren; while underneath, there is a well-preserved past, which is ready to emerge and interrupt the flow of the present (Parrott 6).

\section{Liminality}

Carr truly indicates that theater constitutes a natural space for liminality; where in every work of drama, not only the audience but also the performers suspend reality and come into a sphere in between the real and the pretend a 'heightened realism'. However, liminality in Carr's theater is really existing before performers even take their places on the stage; therefore, it is considered one of the leading forces of Carr's characters and themes in her plays under study in the current research (Campos 12).

As Turner suggests, there are two types of liminality: the first one is ritual liminality, which is a phase in ancient rites of passage processes, while the second type is liminoid phenomena, which is a modern shadow of ritual liminality. Taking into our consideration that ritual liminality is the second of three phases in the rites of passage process of "tribal and early agrarian societies" (53); the first phase is separation, and it is the point at which the subjects separate themselves from conventional society and the previous social structure. While, the third phase is incorporation, which means a welcoming back of the subjects to their new, stable, advanced positions in society. Hence, liminality, in the second stage, is an in-between stage where Turner says, "a sort of social limbo which has few [...] of the attributes of either the preceding or subsequent profane social statuses or cultural states" (24).

Turner claims that in spite of the fact that liminality is a slippery and ambiguous state in between two definite phases in 
Irishness, Female Subjectivity, Domestic Relation, and Landscape as

manifested in Carr's The Mai \& Ariel

Dr. Haitham Mohamed Yehia Abd Elrahman

مجلة وادي النيل للاراسات والبحوث الإنسانية والاجتماعية والتزبوية (مجلة علمية محكمة)

society, the liminal stage indeed includes many distinct characteristics as he states "passage of space" or "geographical movement from once place to another" (25), "physical separation of the ritual subjects from the rest of society" (26), "close connection with non-social or asocial powers of life and death" which really creates a "frequent comparison of the novices with, on the one hand, ghosts, gods, or ancestors, and, on the other, with animals or birds"; liberation from societal and "structural obligations", weakness, since the subjects "have no rights over others" (27); and finally existence in a moment "when the past is momentarily negated, suspended, or abrogated, and the future has not yet begun" (44).

As it is mentioned in advance, the second type of liminality is a shadow of the first one, and it is called, according to Turner, a "liminoid phenomena"; hence, this liminoid stage is an in-between stage or social limbo as same as the liminal stage but without the seriousness and ritual aspects of liminality. Liminoid phenomena are modern and usually manifest themselves in dramatic works, books, films, and any other types of social critique; as same as the liminal phenomena, liminoid phenomena aim at making the subjects think about cultural experiences, but instead of uncovering the rules of society, they expose the injustices of those rules and require the subject to challenge, rethink, and even change those rules.

Due to all what is stated above, and simply as Campos indicates, liminality is a requisite, inevitable, and at times frightening aspect of ancient societies. Liminality, which is part of the rites of passage process, is a serious obligation helping to keep order in a society. On the other hand, liminoid phenomena have no sense of obligation; instead, they are matters of choice and entertainment. Moreover, liminoid phenomena are playful although they have serious implications and critiques of society (15).

According to Campos, the two previous types of liminality actually inspire the critical analysis of Carr's theater; in this context, he points out: 
(ISSN : 2536 - 9555)

..., Carr's works are liminoid phenomena or entertainment. Created by an individual and competing for general recognition in a world of other liminoid phenomena, Carr's works become works of "play": entertaining (if brutal) social critiques that seek to expose the immoralities of contemporary Irish society. Like the liminal phenomena that liminoid works mimic, Carr's characters and audiences enter the Midlands - literally and figuratively - in hopes of critiquing and changing contemporary Ireland. Although Carr's plays contain many liminoid elements and allow for a broad range of social critiques, one of Carr's main venues for social critique actually stems from the second type of liminality - a ritualistic liminality-.... The ritualistic liminality in Carr's works may seem hard to identify given the inherent liminoid nature of her plays. (15)

As a result, it is evident that Carr introduces works of drama which address the current state of flux in Ireland, and she examines the associated tensions in culturally significant styles, which include the blurring of the lines between life and death, fantasy and reality, and among past, present, and future. Therefore, liminality is a central term and theme not only in this research but also in Carr's theater, and as Parrott asserts, Carr expands liminality on her protagonists, frequently appearing in liminal spaces, constantly navigating thresholds and detecting themselves in border areas (18).

\section{The Mai (1994)}

Through playing on the conventions of nineteenth-century naturalism, The Mai is considered a single-set drama affording escape and transcendence through the imaginative circularity and fluidity of the meta-theatrical memory-play form; the play is mainly centered around the lives of four generations of Irish women whose vociferous multiple presences complicate the notion of a single protagonist or the leading role (Sihra 138-139). 
Irishness, Female Subjectivity, Domestic Relation, and Landscape as

manifested in Carr's The Mai \& Ariel

Dr. Haitham Mohamed Yehia Abd Elrahman

مجلة وادي النيل للاراسات والبحوث الإنسانية والاجتماعية والتربوية (مجلة علمية محكمة)

Maccionnaith views that even though The Mai has a few non-realistic aspects which matched up well with many general Irish motifs, it is considered a quite realistic drama and not a too metaphysical one; the play has been structured around a created myth of Owl Lake, based on the actual Irish folklore motifs (40). Hence, myth is employed in The Mai not only to integrate the various folklore images but also to provide a template for its storyline; the watery landscape dominates the play where the protagonists' lives tangle closely with the water and its myth. Furthermore, the previous events in the play were revealed through both water myths and storytelling by the central protagonist Millie, The Mai's daughter who narrates the hidden events about The Mai and Robert's relationship, Grandma Fraochaln, the nine-fingered fisherman, The Mai's London experiences, the effects of Robert's departure on Mai and her family, and the future events such as Millie's failed relationship and the existence of her son. As a result, all these events, surrounding the protagonists, can be seen as reflections of the events in the Carr-created myth of the Owl Lake they live beside.

The opening scene of The Mai states early the importance of landscape in the play when saying "The Mai passes the window, turns to look out on Owl Lake, hears a cello note - decides she is dreaming...Drawn to the window, she looks out at the lake, waiting, watching...then moves again to the window" (Carr "Plays One" 107); in this respect, Sihra contends:

In the play temporality is layered and overlapping, as the action is framed within the frame of the central and dominating window. The view without is of Owl Lake, imagined yet never seen, present in the mind's eye and linked fundamentally to the subjectivity of the eponymous character. In the drama, one-hundredyear old Grandma Fraochlan, a contemporary Cathleen Ni Houlihan, passes the window, currachoar in tow. She is irreverent, boisterous, and 
(ISSN : 2536 - 9555)

demanding, possessing a subversive sense of humour and gleeful, excessive sensibility. (139)

Landscape, in The Mai, plays a vital, major role in the women's lives, and through such tracing for the use of landscape, it becomes evident that Carr sought to demonstrate the positive and negative results of tying one's identity to one's landscape (Parrott 63). Moreover, it is apparent that Carr, in The Mai, pays great attention to the domestic situations of its female protagonists; for instance, the elderly protagonist Grandma Fraochaln, born in 1879 after the traumatic Famine in Ireland, was truly aware of her domestic deficiencies as a mother at the beginning of the twentiethcentury (Sihra 139) when she explains:

...., and I was a useless mother. It's the way we were made! There's two types of people in this world from what I can gather, them as puts their children first and them as puts their lover first and for what it's worth, the nine-fingered fisherman and meself belongs ta the latter of these. I would gladly have hurled all seven of ye down the slopes of hell.... I rot eternally for such unmotherly feelin'. (Carr "Plays One" 182)

Randolph illustrates that Carr, in her Midlands plays, honed a more traditional style in order to deepen the depiction of maternal subjectivities; therefore, she wrote The Mai in a guttural Midlands dialect and set it beside the lakes, rivers, and bogs. In addition, Carr recalls and renegotiates images of women from the national tradition as same as in the earlier plays (48).

According to the narrations told by Millie, Grandma Fraochaln's matriarchal dreams as well as the possibility of escaping to some kind of otherness became "exotic and the unattainable" (Carr "Plays One" 115-116). In this context, Grandma Fraochaln appears ontologically suspended between both her immediate present and the past, which is evoked equally through memory and imagination; therefore, Millie went on narrating how Grandma Fraochaln turned to be a little bit passionate after drinking a few glasses of mulberry wine (Sihra 139) as Millie said, "she began to call up the ghosts and would 
Irishness, Female Subjectivity, Domestic Relation, and Landscape as manifested in Carr's The Mai \& Ariel

Dr. Haitham Mohamed Yehia Abd Elrahman

$$
\text { مجلة وادي النيل للاراسات والبحوث الإنسانية والاجتماعية والتربوية (مجلة علمية محكمة) }
$$

wrestle with them until sleep overtook her. These ghosts were as numerous as they were colourful. One of her favourite buddies from the ghost department was the Sultan of Spain" (Carr "Plays One" 120).

Hence, Grandma Fraochaln, in The Mai, embodies the longing for spaces beyond the boundaries of family and domestic sphere as she says to Beck:

Grandma Fraochaln: Zanzibar. We'll go in an aeroplane through tha sky an' ax them ta stop at Zanzibar.

Beck: Zanzibar, where's that?

Grandma Fraochaln: (one arm out, then the other one) It's way off that way somewhere. What's it like in an aeroplane, Beck?

Beck: Ever sat in a can of beans?

Grandma Fraochaln: (amazed) Jay, we'll go be the currach so. What d'ya think, Beck? Down the Atlantic Ocean, through the Straits of Gibraltar, on into the Arabian Gulf, the hills of Kilimanjira to the left, down be Mogadisha, a little more to the left or is it the right, anyway there we are in Zanzibar! (Carr "Plays One" 167-168)

Grandma Fraochaln, representing the first generation, also embodies an intricately interweaving of the history of four generations of Irish women within precise frames throughout one hundred years; these layered, imaginative, and temporal frameworks embody evidently The Mai's issues of history, sexual politics, the family, memory, and subjectivity from the perspective of each female protagonist. These frames really open a controversy over the radical transitions which women have encountered in the contemporary Irish society; some of these social transitions have been represented in Grandma Fraochaln's discussion with her daughter Julie, a seventy-five years old woman who rejects the practices of her niece Beck, thirty-seven years old who represents 
مجلة وادي النيل للاراسات والبحوث الإنسانية والاجتماعية والتربوية (مجلة علمية محكمة)

(ISSN : 2536 - 9555)

the third generation, for being behave as a whore (Sihra 140) when they argue:

Grandma Fraochaln: Ara, cop onto yourself, Julie! This is the age of freedom, isn't that right, Beck?

Julie: I still call it hoorin' around!

Grandma Fraochaln: Maybe a bit of hoorin' around would've done yourself no harm; might take that selfrighteous straois off your puss! (Carr "Plays One" 141)

As Sihra explains, such experience of Grandma Fraochaln throughout a century constitutes a meta-theatrical framework that is introduced via the memory-narrative of the central storyteller Millie, representing the fourth generation who achieves agency in The Mai through storytelling as well as accessing to oral traditions associated with 'dinseannchas' (place-names), enablement of identity, and the connection with land, narrative, and history (141).

Therefore, landscape becomes not only a source of inspiration but also a consolation to the eponymous protagonist The Mai, who built her home at Owl Lake after her husband, Robert, had left her for another woman. In this vein, Maccionnaith reveals that Millie presents Carr's original myth concerning the story of Owl Lake which was created from 'loch cailleach oiche' as she points out, "Owl Lake comes from the Irish, loch cailleach oiche, Lake of the Night Hag or Pool of the Dark Witch" (Carr "Plays One" 147). Millie continued to tell how this story, in many ways, mirroring the relationship between The Mai and her husband Robert (41); she narrates:

One evening approaching autumn evening Blath told Coillte that soon he must go and live with the dark witch of the bog, that he would return in the spring, and the next morning was gone. Coillte followed him and found him ensconced in the dark witch's lair. He would not speak to her, look at her, touch her, and heartbroken Coillte lay down outside the dark witch's lair and cried a lake of tears that stretched for miles around. (Carr "Plays One" 147) 
Irishness, Female Subjectivity, Domestic Relation, and Landscape as manifested in Carr's The Mai \& Ariel

Dr. Haitham Mohamed Yehia Abd Elrahman

مجلة وادي النيل للاراسات والبحوث الإنسانية والاجتماعية والتربوية (مجلة علمية محكمة)

The legend of Owl Lake, narrated by Millie, outlines The Mai's story as Coillte, who became broken-heart when Blath ignored her for the sake of dark witch, exactly resembles The Mai who became also broken-heart due to Robert's many infidelities; finally, she drowns not only her sorrows but also herself in Owl Lake. Moreover, Millie confesses after narrating the myth of Owl Lake, "A tremor runs through me when I recall the legend of Owl Lake... But we were unaffected by it and in our blindness moved along it like sleepwalkers along a precipice and all around gods and mortals called out for us to change our course, and not listening, we walked on and on" (Carr "Plays One" 148).

Hence, Millie's reflection on the legend of Owl Lake undoubtedly integrates legend and landscape with their influences on the female protagonists' lives as she tells how Coillte's lake of tears created Owl Lake and upon its shore The Mai has built her beautiful house in order to get back Robert to her again; in this context, Millie describes her mother's status by saying, "The Mai sat in front of this big window ......., as if she were pulsing messages to some remote star which would ricochet and lance Robert wherever he was, her eyes closed tightly, her lips forming two words noiselessly. Come home - come home" (Carr "Plays One" 111).

In fact, the house on Owl Lake, which is far from The Mai's family and her original home in Connemara, was built under the guise that The Mai was offered a position at a nearby local school while the fact is that house was located there based on Robert's complaints about the "Connemara click" (Parrott 64-65); thus, we can discover that the distance from her family is a determining factor. Furthermore, such house is not only The Mai's attempt to escape the family's cycle of inertia but also a try to bring Robert back into her life. As a result, the exchange between The Mai and her grandmother proves actually how landscape plays an important role in this drama; The Mai believes that the house, on Owl Lake, will repair her marriage, while her grandmother, Grandma Fraochaln, considered that The Mai has moved away from the west 
مجلة وادي النيل للاراسات والبحوث الإنسانية والاجتماعية والتربوية (مجلة علمية محكمة)

(ISSN : 2536 - 9555)

coast just to live away from her family and away from what she views as the real Ireland. As Roche says:

In choosing to build her house at Owl Lake, the Mai has according to her daughter been 'looking for that magic thread that would stitch us together again.' It is not to be found there, as the play poignantly demonstrates....The Mai is caught in the same inbetween space as Deevy's Katie Roche; both are poised on the threshold between an inner security never experienced and an outer freedom never fully within reach. Millie is of the present and the future, like Marina Carr herself, expressing uncertainty and openness in the telling of a story and the making of a play. (41)

As Maccionnaith disclosed, Carr used several folklore motifs within the story of Owl Lake where it reveals information about the destiny of The Mai in a long time before the end of Act Two. While, at the end of Act One, after finishing the myth of Owl Lake, the stage directions clearly highlighted what has been suggested in those folklore motifs (41) as Carr describes, "Ghostly light on the window. Robert stands there with The Mai's body in his arms, utterly still. Millie watches them a minute. Ghostly effect" (Carr "Plays One" 147-148). So, the reader of The Mai already knows how the play would resolve even though Mai's corpse has not appeared because Carr has expertly woven foreshadowing motifs along the first act.

Turning to another aspect, we can find out that naming of The Mai's some protagonists indeed constitutes another way in which landscape plays a significant role. In particular, Grandma Fraochaln, whose surname comes from the name of the island on which she was born, is an eminent example; as she was probably the only illegitimate child on the island, she was given the island's name as her surname. Thus, it makes Grandma Fraochaln quite literally the owner of the landscape; in this regard, Wallace explores the relationship between Grandma Fraochaln and the landscape when she claims: 
Irishness, Female Subjectivity, Domestic Relation, and Landscape as manifested in Carr's The Mai \& Ariel

Dr. Haitham Mohamed Yehia Abd Elrahman

مجلة وادي النيل للاراسات والبحوث الإنسانية والاجتماعية والتربوية (مجلة علمية محكمة)

The Mai is marked by a tainted heredity which is humorously embodied on stage in the shape of her grandmother. Significantly, Grandma Fraochaln's name emerges as a cipher to the whole family's intricate and unfortunate history of (self) deception. The name is equivocal, functioning to anchor her amid all her flights of fancy to a place of origin and as an implicit reminder of the social stigma of her illegitimacy. (79)

Wallace goes on to explain the ways in which Fraochlan's name affect her female offsprings. She indicates that Grandma Fraochlan and her history are intricately woven into the lives of her children, grandchildren, and great-grandchildren where they are haunted by her conducts, her obsession with the past, and also some factors she cannot control in her life such as her illegitimacy as well as the family's close connection to the landscape (80). In other words, Grandma Fraochlan, in this drama, represents the landscape, and her persistent existence in protagonists' lives prevents the future generations from moving on to their private lives.

Randolph, in the same context, considers that the depiction of woman as maternal and land has been sarcastically subverted in the figure of Grandma Fraochlan, receiving her name from a small island off the coast of Connemara, County Galway, Ireland. And because Grandma Fraochlan paid more attention to her husband rather than her children, this ancient mother-island, who represents a diminutive Mother Ireland, sets in motion a history damaging the future generations of women in such drama (48).

The women in the Mai's family have strong associations with water, and as previously mentioned, Grandma Fraochlan is disappointed that the Mai has chosen to live by a lake rather than the sea. Throughout this drama, Fraochlan is eager to tell narratives of her romance with the nine-fingered fisherman, and in the opening scene of the play, as Millie said, she enters the house with a "huge currach oar moves across the window with a red flag on 
(ISSN : 2536 - 9555)

it" (Carr "Plays One" 111). Fraochlan insists on sleeping with the oar, as she illustrates "it's all I've left of him now" (Carr "Plays One" 113); in one of her narratives, she explains that the ninefingered fisherman, who died sixty years earlier, had once referred to her as the "Queen of the ocean" (Carr "Plays One" 121).

On the other hand, Millie's association with water is probably the most complicated, where she definitely senses the danger inherent in it greater than Grandma Fraochlan or The Mai. As she and Robert search through different types of blue fabric for the dress to bury her mother in, Millie describes the behavior of the people surrounding them by saying:

Still reeling from the terrible events of that weekend, we walked through The Midland drapery, the floorboards creaking, the other shoppers falling silent and turning away, they knew why we were there and what we'd come for, afraid to look yet need to see, not wanting to move too closely lest they breathed in the damaged air of Owl Lake that hung about us like a wayward halo. (Carr "Plays One" 128-129)

In contrast to the rest of the women in her family, Millie has a more cautious relationship with water, particularly after The Mai's death in Owl Lake, as she takes great pains to distance herself from that landscape. Therefore, she immigrated to New York where she gave birth of a child out of wedlock and acknowledged, "I thought it possible to have something for myself that didn't stink of Owl Lake" (Carr "Plays One" 165). Her desire to keep her son away from the poisonous air surrounding Owl Lake contradicts her obsession with it. Even though Millie physically leaves the Midlands and Ireland in general, mentally she remains in the house with all of her female ancestors; she states:

Images rush past me from that childhood landscape...The Mai at the window, Grandma Fraochlan's oar, Julie and Agnes colluderin' in the corner, The Mai at the window again. The Mai at the window again, and it goes on and on till I succumb and linger among them there in that dead silent world 
Irishness, Female Subjectivity, Domestic Relation, and Landscape as manifested in Carr's The Mai \& Ariel

Dr. Haitham Mohamed Yehia Abd Elrahman

مجلة وادي النيل للاراسات والبحوث الإنسانية والاجتماعية والتربوية (مجلة علمية محكمة)

that tore our hearts out for a song. (Carr "Plays One" 184)

Millie's liminal status as both narrator and participant in the actions of this drama demonstrates her inability to separate herself from Owl Lake; as a result, her final monologue mainly concentrates on her relationship to water and her memories of Owl Lake where she admits:

We teeter along the fringe of the world with halting gait, reeking of Owl Lake at every turn. I dream of water all the time. I'm floundering off the shore, or busting towards the surface for air, or wrestling with a black swan trying to drag me under. I have not yet emerged triumphant from those lakes of the night. Sometimes I think I wear Owl Lake like a caul around my chest to protect me from all that is good and hopeful and worth pursuing. And on a confident day when I am considering a first shaky step towards something within my grasp, the caul constricts and I am back at Owl Lake again. (Carr "Plays One" 184)

Just as The Mai and her ancestors physically buried in the graveyard bog, they will eternally remain at Owl Lake; while, Millie will mentally confine to the landscape as well. In addition to foreshadowing, her mention of the black swan echoes The Mai's story of Sam Brady, who sold her the land "for a song" and who, in his strong disapproval of Robert, kills a black swan and leaves its mate loudly keens. Thus, it is evident that The Mai is fixated on the image of the keening swan and after her death at the end of this drama, the final stage directions indicate, "Millie watches The Mai looking out the window. A few seconds later, The Mai turns and drifts from the room. Sounds of geese and swans taking flight, sounds of water" (Carr "Plays One" 186).

The Mai's characters obviously have a strong relationship with the landscape, and their connection is actually so strong that they equate their deaths with a return to it; in this regard, Grandma Fraochlan says, "when my time comes I'm to be thrun into the wide 
(ISSN : 2536 - 9555)

Atlantic! D'ye all hear that? Twenty mile sou'west of Fraochlan where the nine-fingered fisherman's currach went down! D'ye hear me now!" (Carr "Plays One" 180). Simply, we can discover that Fraochlan distinctly equates the sea with her love for the ninefingered fisherman and in returning to the sea after her death, she hopes to return to him and to their relationship, just as The Mai returns herself to Owl Lake and to all of the hopes she had for her relationship with Robert when she first built the house there.

Agnes and Julie, the second generation in their sixties and seventies, represent the key conflicts in The Mai as they are collusive with the confining ideologies of the Catholic Church and emergent Ireland. They considered that the nature of the woman is just determined by being either noble or ignoble as both the enshrined church and the definition of the woman in the Family Article of the Irish Constitution state (Sihra 141). But similarly to the most of their family members, Agnes and Julie plan to spend their afterlife in the midland bog, as Julie's Christmas gift to Agnes is a piece of land next to her in the graveyard near the bog; this appears in their conversation when they say:

Agnes: Julie bought me a plot beside her own for Christmas.

Julie: Well it's not exactly beside mine. It's the other side of Michael. It was the nearest I could get. (Carr "Plays One" 179-180)

Moreover, The Mai seeks solace in Owl Lake because the story of Coillte and Blath mirrors that of her strained relationship with Robert, and she ultimately follows in Coillte's footsteps by drowning herself in the lake. Therefore, water, according to The Mai's view, brings the promise of both the death of a torturous relationship and the promise of rebirth and the chance to start over in another realm.

In this vein, we can say that water constitutes a liminal space where it gives and takes away; it takes the lives of The Mai and the nine-fingered fisherman, but it also gives a great deal of comfort to Grandma Fraochlan. Similarly, Ireland is an island surrounded by rough seas, which have both provided food and 
Irishness, Female Subjectivity, Domestic Relation, and Landscape as manifested in Carr's The Mai \& Ariel

Dr. Haitham Mohamed Yehia Abd Elrahman

$$
\text { مجلة وادي التيل لللاراسات والبحوث الإنسانية والاجتماعية والتربوية (مجلة علمية محكمة) }
$$

income to many families living on the coast, but which have also posed a great danger to those who were forced to make their living by the sea. There are countless stories of people like the ninefingered fisherman whose lives ended when the rough waters overtook the small currachs or boats that were used for fishing and travel. As a result, the landscape is inextricably linked to the past, present, and future of The Mai's characters, and their identities are inextricably bound to it whether they like it or not.

Eventually, we can say that Carr's The Mai is set in the Midlands where the bog is prominent, however, in this drama the landscape is focused on bodies of water, Owl Lake, respectively. The Mai spends most of her time in her new house looking at the window in front of Owl Lake, and she is framed in windows during the play's events gazing at the lake. Consequently, we come to the fact that the window in this drama is the liminal space, the portal that allows The Mai to look away from her domestic interior out onto Owl Lake, and the narrative, which consoles her during the disordered marriage to Robert.

At this point, we notice that The Mai's habit of looking out onto the lake, watching for Robert's return, is something that Grandma Fraochlan used to do with the nine-fingered fisherman; this is evident in Fraochlan's discussion with her daughter Julie who confirms, "you didn't bring me up at all. I brought myself up and all the others. You were at the window pinin' for the ninefingered fisherman!" (Carr "Plays One" 141). Hence, Julie acts here as same as Millie, who discusses The Mai's fixation on the window on Owl Lake and on Robert's return as she says, "None of The Mai and Robert's children are very strong. We teeter along the fringe of the world with halting gait, reeking of Owl Lake at every turn" (Carr "Plays One" 184).

On another side, we can assert in accordance with Parrott's analysis that The Mai's family has a history of occupying windowframes in an attempt to turn their domestic realities into romantic fairytales; thus, the younger generations are left to fend for themselves and to occupy their own liminal space in terms of 
(ISSN : 2536 - 9555)

childhood and adulthood. As a result, the children, in this drama, are forced to grow up too fast and eventually inherit the problems of the generation of women, who preceded them (80-81).

Wallace points out that the strength of The Mai is often attributed to its engagement with eternal and essential dilemmas. The notion of destiny, allusion to myth, folktale and a harsh version of midland speech permeate Carr's writing to such a degree that in many respects it hardly seems of the contemporary world ("Authentic Reproductions" 43). In addition, Carr keeps exploring questions of identity and ontology through her employment of narrative within this drama; thus, the tales of Owl Lake facilitates a metonymic shift where the protagonists are doubled in other fictions ("Authentic Reproductions" 62).

Ultimately, what makes Carr's The Mai the best-received and the most important literary work is its ability to explore the gray areas existing between the binary poles that are predominantly used when discussing Ireland. In this drama, as Parrott indicates, Carr explores themes which are in-between such as the uneven and unpredictable bogs of the Irish Midlands, the liminality of ghosts existing somewhere between life and death, the female protagonists trapped between their natural sex and the socially constructed gender roles of wife and mother, the status of the Traveller community existing somewhere between native Irish and nomadic outcasts, and finally the temporal setting, which blurs the lines between past, present and future (132).

\section{Ariel (2002)}

Ariel is Carr's another version of a Greek tragedy which is set in the Irish Midlands. As Morrison explains, Ariel, which is mainly based on Euripides' Iphigenia at Aulis with great consideration to Aeschylus' Oresteia and Sophocles' and Euripides' two versions of Electra, introduces the story of the central protagonist Fermoy Fitzgerald; in this context, Morrison gives a detailed explanation for the meaning of Fermoy's name where he says "Fermoy (whose name, "Fear Mai" in Irish, in English suggests fer = "for" and Moi = "me," "For myself," which this man 
Irishness, Female Subjectivity, Domestic Relation, and Landscape as manifested in Carr's The Mai \& Ariel

Dr. Haitham Mohamed Yehia Abd Elrahman

مجلة وادي التيل للاراسات والبحوث الإنسانية والاجتماعية والتربوية (مجلة علمية محكمة)

certainly is - Sinn Fein's "ourselves alone" has become "myself alone")" (1).

In this drama, the central protagonist, Fermoy, is politically competing with a man called Hannafin and for the sake of being a Taoiseach, Fermoy is willing to sacrifice his own daughter, Ariel, upon a divine command in order to maintain his political success and career; hence, Fermoy, in Carr's Ariel, embodies the modern version of Agamemnon's personality as he also has political aspirations as same as the ancient protagonist (Morrison 1).

We may discover that one of the major aims of Carr's Ariel is to force her readers to reconsider the performance of Irish identity on the stage. In this regard, Hughes investigates the accuracy of Irish identity depiction on the contemporary stage as he claims, "To reinvent ourselves for the future, to stop defining ourselves in terms of the past. Identity is inchoate; it's up for grabs, it must be constantly reinvented: like theatre, made new every day" (9); he adds:

I'd like to see Irish theatre embrace the profound change that has occurred: that we are barely a country any more, never have been and never will be that most nineteenth century of dreams, a nation once again; that our identity is floating, not fixed.... I think it's significant that.... so much attention gets paid to the nineteen fifties, the decade before Ireland opened for business, the time when we were a "special little enclave"... I never again want to see an Irish play set in a community where everyone talks and thinks the same and holds values in common. Because that is not truth: that's nostalgia: the illusion that there is something that still binds us together. Increasingly, there isn't... But we don't know who we are any more. There's a fair possibility that we never will again. (13-14)

Parrott indicates that Irish theater has established itself as its own genre and therefore readers have specific expectations from 
(ISSN : 2536 - 9555)

Irish Drama, including a certain level of realism as well as explicitly Irish content (161). Therefore, it is evident that Carr continuously plays with readers' expectations as she often incorporates elements traditionally associated with Irish theater, however, she also subverts them in an attempt to address the contradiction between traditional tropes and contemporary realities of Ireland's life at the end of the last century and the onset of the twenty-first century.

The characters, in Ariel, adopt the opposite approach to conquer a troublesome family history. Fermoy, the central protagonist of the play, possesses absolute lust for political success in the Dail and never stops at nothing to win the subsequent election; hence, he brought his family into the public eye by sacrificing his daughter, Ariel, as he thought that God asked him to do so. In order to achieve his goal, Fermoy buys a car for Ariel's sixteenth birthday to use it in his plot against her, and after taking her father for a drive through the country, she vanished; ten years later after Ariel's disappearance, Fermoy carries on mining his family tragedy to gain both sympathy and political support from Irish voters on his quest to become Taoiseach.

Ultimately, Frances, Fitzgerald's wife, came to the fact that Fermoy killed Ariel, and afterwards she stabbed him to avenge her daughter's death before Fermoy became Taoiseach. Two months later, when Ariel's remains are discovered at the bottom of Cuura Lake, Frances, who was on leave from prison for the burial, was also killed by her daughter Elaine, who has always been involved in her father's political career. In fact, not only Fermoy's political career but also the play ended in a bloodbath; Fermoy's practices to create a New Ireland parallels the long and violent process of establishing an independent Irish republic at the end of the last century.

In this drama, Carr presents a model of family trying to conceal her humiliating past; the Fitzgeralds is considered a vengeful example because Fermoy Fitzgerald kills his own daughter, Ariel, in a sacrificial attempt to win a public governmental position, and he is ultimately killed by his vengeful 
Irishness, Female Subjectivity, Domestic Relation, and Landscape as manifested in Carr's The Mai \& Ariel

Dr. Haitham Mohamed Yehia Abd EIrahman

مجلة وادي التيل للاراسات والبحوث الإنسانية والاجتماعية والتربوية (مجلة علمية محكمة)

wife, who in turn is killed at the hand of her vengeful daughter. While the Fitzgeralds take fate into their own hands, they murder each other in an ever-growing chain of violent revenge (Parrott 163). Thus, we come to the fact that Carr, in Ariel, undoubtedly does not present the Fitzgeralds as a typical Irish family; however, she poses issues of political corruption and national identity which attract her readers' attention and demanding public discussion.

As Parrott illustrates, the setting of Ariel is more complex than The Mai; like Carr's four previous works of drama, this play is also set in the Midlands. Nevertheless, the only clue is a passing remark by Fitzgerald's brother Boniface who, in a drunken stupor, raises a glass and proclaims, "May God have mercy on your carcass, and may he have mercy on mine. Up Offaly" (Carr "Plays Two" 114); while, the only other geographical landmarks, in such drama, are the fictional Cuura Lake and the official buildings of the government in Dublin where Fermoy works (164). Hence, it is clear that Carr's Ariel exists somewhere between the rural geography of the Midlands and the urban topography of Dublin.

Trotter views that Carr introduces haunting images of the Irish midlands which are considered by the critics the richest images of Irish language, spirit, and life (188). She adds, "Carr's plays imagine the Irish countryside as a hybrid landscape, where tradition and innovation, belief and reason, the abject and the oppressive cohabitate" (189); this hybridity is evident in the fact that the contemporaneity of Ariel disputes its ancient Greek roots, as Carr draws heavily from Euripides' Iphigenia at Aulis to broach the subjects of national identity, government corruption and greed in contemporary Ireland. Hence, Carr, in this drama, maintains her established strategy of turning to the past as a way to broach the difficult issues facing Ireland in the present, but what distinguishes Ariel from Carr's previous works of drama is the prominence of Greek tragedy.

Murphy emphasizes that, "The landscape of the midlands plays reflects Carr's dramatic world, which is quite literally 'mid' or in between, wedged in the interstices of realism and fantasy, 
(ISSN : 2536 - 9555)

ancient and modern, local and global" (393). In addition, Murphy explains how Carr employs liminal space in her works of drama as she says, "Carr's drama reflects the liminal status of both Irish dramaturgy, poised between the post-colonial and postmodern, but also Ireland itself, which having rushed headlong into modernity and postmodernity finds its communal identity an uncohesive blend of old and new" (393).

The liminality, in such drama, is evident in an intricate setting where the rural and urban as well as the ancient and modern manifestations are simultaneously presented; throughout Ariel, Carr portrays the present and past in a liminal tension as they are depicted in Ariel's car parked next to her father's cement Greek lions.

Moreover, direct references to both Greek tragedy and contemporary Irish society are contained at this drama. There is a direct parallel between Iphigenia and Ariel, as Iphigenia is initially tricked into the sacrifice through the promise of marrying Achilles; at the same time, Ariel is also tricked into giving up her life at the promise of exercising her unprecedented freedom by taking her father for a tour in the new car given by him in her birthday. Eventually, we can discover that there is a clear contradiction between the two protagonists as Iphigenia chooses to sacrifice herself out of honor in order to help her father gaining favorable winds to go fight the Trojan War; however, Ariel does not have the same selection space as she is sacrificed by her father so that he may win a political war against Hannafin for gaining a seat in the Dail.

Carr interweaves the Greek ideas of familial duty into an ironic contradiction with the corrupted ideas of family presented through Fitzgeralds. She also uses Ariel's ghost in haunting Fermoy; this use might appear in Ariel's phone call with Fermoy when she terribly wept and asked him, "I don't know ... I want to go home ... I just want to go home. Please, just brin me home" (Carr "Plays Two" 123). As a result, it is evident through this phone call that 'home' mainly constitutes a complicated place in this drama; for instance, Ariel considers home as a place where her 
Irishness, Female Subjectivity, Domestic Relation, and Landscape as

manifested in Carr's The Mai \& Ariel

Dr. Haitham Mohamed Yehia Abd Elrahman

مجلة وادي النيل لللداسات والبحوث الإنسانية والاجتماعية والتريوية (مجلة علمية محكمة)

mother permanently mourns the loss of her previous family, a place which reminds her how Fermoy helped in killing her grandmother, and the place where she anticipates in advance her own death before falling asleep at night where she says to her mother:

I know ud's mad, buh I never thought I'd make me sixteenth birthday. I've this thing abouh a girl in a graveyard, don't know where ud cem from, buh just before I go to slape and me mind's blanked ouh, this sintince kapes comin. Girl in a graveyard, girl in a graveyard, I tap ud ouh on the pilla, puts me to slape like a lullaby. (Carr "Plays Two" 91)

Ariel's dreams foreshadow her death, as she is killed on her sixteenth birthday, and almost everyone else in her family faces a bloody death at this home as well. So, Fitzgerald's home becomes an ironic contradiction to the traditional representations of the Irish home as it does not become a shelter for the family anymore; instead, it turned to be a lethal battlefield where no one is safe. In this regard, Parrott explains that because of Ariel's recurrent dreams, her lifetime has been spent in a liminal state, as she always expects her death in these dreams, which constitute a liminal state between conscious and unconscious states (169).

Carr's Ariel directly deals with Ireland's identity, as Fermoy seeks to reshape the country onto his own vision. This is clear in his dialogue during the interview with the press on the tenth anniversary of Ariel's death where he admits, "We nade to reimagine ourselves from scratch. [...] I chose Education because ud all begins and ends wud education. And my business righ now is to re-educahe a nation. Thah won't be done in a day" (Carr "Plays Two" 106-107). Thus, Fermoy's position as the minister of education is very essential because he believes that identity is not inherited from ancestors. However, identity is acquired via learning, and it is something that must be taught not only through formal education such as teaching Irish language and history, but 
(ISSN : 2536 - 9555)

also through informal education such as national festivals, theatrical performances, music, folklore, and so on.

This shaping of identity can best be embodied when Fermoy goes through the process of editing his television interview upon Elaine's suggestion to revise it as she wants to cut off Fermoy's confession that he has a lust for power; she also wants him to shift the focus off of religion and to exploit Ariel's death further. On the other hand, Elaine rejects the interviewer's suggestion to hold back a bit on the subject of Ariel while Fermoy agrees; in this context, he tells Elaine, "Leave ud. Migh as well be hung for a sheep as a lamb" (Carr "Plays Two" 111). The process of editing the interview exposes the construction of identity; in this vein, Fermoy, Elaine, and the interviewer all weigh in on how Fermoy should be presented to the public, proving that identity, whether personal or national, is not organic; however, it is constructed, molded, and edited. Hence, identity is the product of a conscious process, and identity formation in Ireland predominantly takes place on stage. At this point, Carr departs from many but not all of her predecessors in her disclosure of the process of identity formation. She creates a work of art and participates in the Irish dramatic tradition as well as responding to the artists and texts that preceded her.

Carr, in Ariel, clearly exposes the corruption in the Irish political arena and she presents characters who seek to present themselves as they wish to be perceived, creating false identities to further the development of the simulacrum, putting another layer between themselves and the truth. Through the hyperrealities or the inability of consciousness to distinguish reality from a simulation which presented in Ariel, Carr demonstrates the deep corruption she views in Ireland and the unwillingness to look at its own weaknesses. In effect, Ariel is the first of Carr's literary works which shifts the focus from the private, domestic realm to the public realm and the larger scale entities of the Catholic Church and the government; it deals directly with political power, the role of the church, and national education, which aligns the play with 
Irishness, Female Subjectivity, Domestic Relation, and Landscape as

manifested in Carr's The Mai \& Ariel

Dr. Haitham Mohamed Yehia Abd Elrahman

مجلة وادي النيل للاراسات والبحوث الإنسانية والاجتماعية والتربوية (مجلة علمية محكمة)

Greek concerns (Parrott 174). Therefore, Leeney views Carr's Ariel as follow:

Ariel is excessive and epic in its passions. Its scope reaches beyond life into the world of hauntings, beyond good and evil into the seductiveness of power for its own sake, and beyond the past and future into a terrifying eternity, past imagination, yet echoing the darkest conceivable imaginings of chaos and savagery. (513)

She outlines the fundamental disconnect between the surface and the underlying forces in such drama as Leeney says:

$\ldots$ on the surface it is a play about an Irish family; birthday cakes are baked; the cement business pays the bills; and the world of politics and media as we recognize it is reflected and sent up in the television interview scene between Fermoy and a slick current affairs presenter. Besides the ways in which they echo the tragic families of Euripides and Aeschylus, how do these forgings together of the domestic and the epic work in the play? Two aspects of Ariel prompt a reading with a wider meaning than the bloody tale of a doomed family, and a wider meaning even than the Fitzgerald family as a parallel for the state of Ireland under the Celtic Tiger, prey to corruption, private ambition and the ruthless selfinterest of those in power. (513)

Leeney, at this point, comments on the tension between the mundane existence of a typical Irish family and the grandiose, epic scale of both Fermoy's ambitions and the ambitions of this drama as a whole.

Evidently, this tension between epic and trivial has been confirmed through the architecture of the Fitzgerald's home; in spite of the fact that this home set in the Midlands, it does not look like the dwellings of Carr's trilogy. It resists the surrounding landscape in many ways in sharp contrast to the Mai's home 
(ISSN : 2536 - 9555)

inspired by Owl Lake and Hester's Caravan allowing her to be close to the bog. Furthermore, its ostentatious is a significant attempt to mimic classical Greek architecture with columns, lions, and fountains; instead, what is important is the fact that these Greek elements are not decorated with marble used in ancient Greece or stone found in abundance throughout Ireland. However, they are made of cement, an appropriately man-made material produced by a self-made family.

We find out that Fitzgerald's home is a cheap imitation of the ancient Greek architecture; in this respect, it is evident that this dwelling symbolizes to the family that lives in it. Through Fermoy's attempt to superimpose Greece on top of contemporary Ireland, he takes things too literally and distant while his plan and ambition result in his death and the demise of most of his family.

According to Parrott, the Fitzgeralds' obsession with cement is an indication of a greater trend of a waning link between protagonists and their natural surroundings in Carr's recent works. In fact, all the female protagonists of the Carr's trilogy have deep links with the land which they live on; therefore, The Mai's home is inspired by Owl Lake, Portia, in Portia Coughlan, is solaced by the Belmont River, and finally Hester, in By The Bog of Cats, rejects to be removed from the Bog. However, protagonists, in Carr's recent plays following this trilogy, begin to lose their affinity for the natural landscape (176).

Based on the aforementioned, it is clear that the characters, in Ariel, are more alienated from their natural surroundings. Actually, the only natural landmark in this drama is Cuura Lake, where Fermoy's mother was drowned and where Fermoy drowns his daughter, Ariel, on her sixteenth birthday. The lake is little more than a repository for dark secrets and decaying bodies, however, it does not serve as a source of consolation or inspiration as the lakes and rivers of the trilogy do. In this respect, Fermoy ironically blames the polluted state of the local environment on his political opponent, Hannafin as he says, "And whah abouh your symmetry, Hannafin [...] that new asbestos plant, there's noh a lake or river we can swim in any more, thanks to you. And thah 
Irishness, Female Subjectivity, Domestic Relation, and Landscape as manifested in Carr's The Mai \& Ariel

Dr. Haitham Mohamed Yehia Abd Elrahman

مجلة وادي التيل للاراسات والبحوث الإنسانية والاجتماعية والتربوية (مجلة علمية محكمة)

piggery, who's been fundin thah all these years? There's lots a questions to be asked concerning you if ya want to play ud thah way" (Carr "Plays Two" 96).

Fermoy blames Hannafin for the pollution of the area's natural resources as an attempt to conceal his family's contribution to the pollution with two dead bodies rotting in Cuura Lake. On the other hand, a key point here is that the characters are reviled by rather than the link with their natural surroundings. Early in this drama, Fermoy tells his brother, Boniface "The earth's over, paple knows thah in their bones, ozone layer in tahhers, oceans gone to sewer, whole world wan big landfill a dirty nappies. We're goin to lave this place in ashes like the shower on Mars" (Carr "Plays Two" 76). Hence, nature is associated with death in such drama, and the idea of rebirth presented in Carr's Midlands Trilogy is not presented here. As a result, it is clear that the possibility of rebirth or a loving reunion is absent from Ariel, while all the protagonists, in Carr's Trilogy, commit suicide in nature as a way of returning to the earth hopes of reuniting with a loved one.

As the water in Ariel lacks these redemptive qualities, Carr gives a brief description of Cuura Lake, and the only other form of water mentioned in this drama is that which flows through the cement fountains on the Fitzgeralds' property. Thus, the juxtaposition of man-made cement and flowing water complicates the idea of nature, and it suggests that Fermoy's desire to power is unnatural, despite his claims to the contrary; Fermoy manufactures the cement to create the fountain and redirects the natural flow of water so as to force it to flow through it. Consequently, Cuura Lake has no redemptive qualities unlike Owl Lake, the Belmont River, and the Bog of Cats. Although the protagonists, the Mai, Portia, and Hester in Carr's Midlands Trilogy, take their lives in the aforementioned watery places, they always find solace in these sites and view them as a method of escape.

Carr's female protagonists use the watery places as outlets, as portals into a world where they can lead the lives they desire without judgment from the societies in which they live. Water kills 
(ISSN : 2536 - 9555)

these women physically, but it gives them a freedom that they could never experience on earth. However, unlike the Mai, Portia, and Hester, Ariel does not find solace in the water, and she does not choose to take her own life; in this sense, nature is destructive rather than restorative, which breaks significantly from Carr's previous use of natural landscape, presenting a liminal environment that features man-made cement channeling the natural water.

In Ariel, as Parrott mentions, the liminal existence of the characters, stands obviously in contrast to the characters in most of Carr's previous dramatic works. Particularly, unlike the Raftery's family, the Fitzgeralds desire change and they are willing to take actions to bring about those changes. While, most of these actions are failure and drive the family members to their final doom (179). Hence, death looms over the characters from the beginning of this drama, when it is revealed that Fermoy and his brother Boniface helped their father drown their mother in Cuura Lake. While both men have developed excuses to calm down their guilt, Frances literally carries the death of her first husband and child around her neck in the form of a locket, which houses photos of both of the deceased. She is often accused of feeling more at home in a graveyard, and it is clear that she is not entirely alive, that part of her died with her first family.

The excuses developed by Boniface and Fermoy to deal with their guilt are indications of how drastically they differ from Frances in responding to death; therefore, on the tenth anniversary of Ariel's death, Frances urges Fermoy to hurry in order not to be late for Ariel's mass and Fermoy, "Don't you talk to me abouh mournin. [...] Most gets up offa the ground sooner or laher, dusts themselves down, rejines the land a the livin. Not you though. [...] Live! Live! Live! That's whah we're here for. Do something! Anhin!" (Carr "Plays Two" 116-117). Fermoy is an ambitious man of action, and he is frustrated by Frances's inability to recover from the death of her ex-husband and son; he suggests that Ariel is not actually alive, but she exists somewhere between life and death; 


\section{Irishness, Female Subjectivity, Domestic Relation, and Landscape as manifested in Carr's The Mai \& Ariel}

Dr. Haitham Mohamed Yehia Abd Elrahman

$$
\text { مجلة وادي النيل للاراسات والبحوث الإنسانية والاجتماعية والتربوية (مجلة علمية محكمة) }
$$

she is more comfortable closer to the death side of the binary than to the living side of it.

In this drama, we may discover that the characters exist in a state somewhere between life and death; they are physically alive, but they are controlled by a power greater than themselves. For instance, it is evident that Frances is controlled by her grief, Boniface is controlled by bitterness, and Fermoy is controlled by his greed and lust for power. As a result, these characters constitute rigorous contradictions to Carr's female protagonists in her Midlands Trilogy, who ultimately controlled how and when their lives would end.

In effect, via Carr's theater, she intends to say that the approach to a complete change in both Ireland and its theater is not a healthy trend; from her point of view, the past cannot be blindly preserved forever while it cannot be obliterated in a fit of anger. Therefore, in Ariel, through the furious struggle of its characters to change their lives, Carr directly deals with changes in Ireland, which brought on by the Celtic Tiger. At this respect, Carr has refrained in this drama from directly discussing issues affecting contemporary Ireland such as the Irish landscape, accent, and folklore which always play a role in her works.

We can say that Ariel is quite different from Carr's midlands trilogy; it represents the contemporary time in large part due to the fact that Carr presents her audience with the issues of the reducing dominance of the Catholic Church, a rising population and middle class, and a prosperous economy that depends on industry and technology rather than agriculture. However, Ariel resembles Carr's midlands plays as they have been set in the present era, but we often feel that all of them take place earlier in the twentieth century.

The major and important questions posed in Ariel are how Ireland will move forward towards the future and how Ireland will re-imagine itself in the wake of the Celtic Tiger. In Ariel, Carr fights against easy answers as usual, instead choosing to remain in liminal tension; therefore, this drama exists in a liminal setting 
(ISSN : 2536 - 9555)

which contains elements of both ancient Greek drama and contemporary Irish popular culture. It also contains a ghost who haunts her killer through a cell phone in spite of the fact that Ariel is modeled after Euripides.

Throughout this drama, Carr offers Fermoy, an Irish politician willing to do anything to attain power. She also presents the characters who surround him and who are equally incapable of defining themselves; those characters are really dependent on their family members in order to form their identity. Thus, we may notice that Stephen cannot separate himself from his mother and consequently is nursed until he is ten, Frances cannot separate her life from the death of her children and consequently wears her grief like an albatross around her neck, Elaine cannot exist without her father and consequently murders her mother, and Boniface cannot escape the guilt of killing his mother and consequently stays in the monastery as protection from it.

At the empty heart of the Fitzgerald family lies Ariel, whose life and death carry the cycle of death violence more forward in such drama. Appropriately, through her desire to move forward, Ariel's death is brought about where she simply wants to practice her new freedom by driving her new car. Above all else, the Fitzgeralds are active and their insistent desire to overcome any obstacle in their paths, no matter the cost, is eventually the cause of their destruction; therefore, at the end of this drama, we may realize that Fitzgeralds are so active and extremely eager to destroy the past; they act on their emotions before fully considering the consequences. Ultimately, they do not achieve their goals, which land them in the position they tried to escape in the first place.

To sum up, Carr's Midland plays are comprised of many layers. The top one contains the protagonists' dwellings, experiences, struggles, and identities; however, under this top layer lie their histories which present the bodies, stories, struggles and identities of their ancestors. As a result, the protagonists, in Carr's plays, mine the landscape for these histories as a way of helping them to overcome the difficulties with which they have encountered throughout their own lives; hence, Carr mines the 
Irishness, Female Subjectivity, Domestic Relation, and Landscape as manifested in Carr's The Mai \& Ariel

Dr. Haitham Mohamed Yehia Abd Elrahman

مجلة وادي التيل للاراسات والبحوث الإنسانية والاجتماعية والتربوية (مجلة علمية محكمة)

Midlands landscape in an attempt to make sense of the dramatic changes occurred in Ireland Republic (Parrott 62). Furthermore, Trotter states that some critiques, in Ireland, have been claimed that new representations of Midlands and rural Ireland stem from the anxiety over swift urbanization and economic growth in Celtic Tiger Ireland (190); while, Vic Merriman indicates that Carr's success as well as her fame have been built around works which stage Ireland as a benighted dystopia, and how Carr directs her readers' attention towards the poor, the past, and Irishness (312313).

In conclusion, it is obvious that Carr's plays - The Mai 1994 and Ariel 2002 - illustrate how the concept of liminality has been employed as a way for the protagonists in these works of drama to re-imagine their real conditions. They allow readers to re-imagine the rapid change of Irish culture and community, which displays a postmodern self-awareness in the plays' multiple meta-theatrical elements. Moreover, these two plays display Carr's use of local folklore not only for establishing the history of the landscape but also for reflecting the universality of her female protagonists' struggles. Hence, Carr, through these histories of the landscape, seeks to integrate the topography of the Midlands with inner struggles of the characters against the social construction of women's gender roles.

\section{Works Cited}

1. Bacik, Ivana. Kicking and Screaming: Dragging Ireland into 21th Century. Dublin: O'Brien, 2004. Print.

2. Butler, Judith. "Performative Acts and Gender Constitution: An Essay in Phenomenology and Feminist Theory." Theatre Journal 40.4 (1988): 519-531. Print.

3. Campos, Hillary Jarvis. Marina Carr's Hauntings: Liminality and The Addictive Society on and off The Stage. Brigham: 
(ISSN : 2536 - 9555)

Masters of Arts in English Brigham Young University, 2008. Print.

4. Carr, Marina. Marina Carr: Plays One Low in the Dark. The Mai. Portia Coughlan. By the Bog of Cats ... London: Faber and Faber, 1999. Print.

5. ---. The Mai. Marina Carr: Plays One Low in the Dark. The Mai. Portia Coughlan. By the Bog of Cats ... London: Faber and Faber, 1999. Print.

6. ---. Marina Carr: Plays Two On Raftery's Hill, Ariel, Woman and Scarecrow, The Cordelia Dream and Marble. 2009 London: Faber and Faber Ltd, 2009. Print.

7. ---. Ariel. Marina Carr: Plays Two On Raftery's Hill, Ariel, Woman and Scarecrow, The Cordelia Dream and Marble. 2009 London: Faber and Faber Ltd, 2009. Print.

8. Gray, Breda and Louise Ryan. "The Politics of Irish Identity and the Interconnections between Feminism, Nationhood, and Colonialism." Nation, Empire, Colony: Historicizing Gender and Race. Ed. Ruth Roach Pierson and Nupur Chaudhuri. Bloomington: Indiana UP, 1998. 121-138. Print.

9. Hughes, Declan. "Who the Hell Do We Think We Still Are? Reflections on Irish Theatre and Idenity." Theatre Stuff: Critical Essays on Contemporary Irish Theatre. Dublin: Carysfort, 2000. 8-15. https://books.google.com.eg/books?id=MuMWMy5Hx9oC $\& p g=\mathrm{PA} 8 \& \mathrm{lpg}=\mathrm{PA} 8 \& \mathrm{dq}=\mathrm{Who}+\mathrm{the}+\mathrm{Hell}+\mathrm{Do}+\mathrm{We}+\mathrm{Think}+$ We + Still+Are?+Reflections + on+Irish + Theatre+and+Identit y.\&source=bl\&ots=AXa6qzm0gl\&sig=CZ91_coL9i5pJHM 9JUpUcN-

TqlE\&hl=en\&sa $=$ X\&ved=0ahUKEwi0g9vep4XNAhWMCc AKHZoaA-sQ. Accessed 25 January 2021.

10. "Irish Constitution Art. 41 (2. 1-2)." 13 January 2004. International Constitutional Law. Ed. Tschentscher. $<$ http://www.servat.unibe.ch/icl/ei00000_html $>$. Accessed 15 November 2020.

11. Leeney, Cathy. "Marina Carr: Violence and Destruction: Language, Space and Landscape." A Companion to Modern 
Irishness, Female Subjectivity, Domestic Relation, and Landscape as manifested in Carr's The Mai \& Ariel

Dr. Haitham Mohamed Yehia Abd Elrahman

مجلة وادي النيل للاراسات والبحوث الإنسانية والاجتماعية والتربوية (مجلة علمية محكمة)

British and Irish Drama: 1880 - 2005. Ed. Mary Luckhurst. Oxford: Blackwell Publishing Ltd, 2006. 509-518. Print.

12. Maccionnaith, Eric-Michael. Resurrection: The Use of Folklore Themes and Motifs in Marina Carr's Worrks. Oregon, 11 March 2008. <www.oqdt.com>. Accessed 5 June 2020.

13. Merriman, Vic. "Decolonisation Postponed: The Theatre of Tiger Trash." Irish University Review 29.2 (1999): 305-317. $<$ http://www.jstor.org/stable/25484817 > . Accessed 13 June 2020.

14. Morrison, Conall. "Marina Carr's Ariel Reviews: A Light Angel in a Dark Landscape." Didaskalia - The Journal for Ancient Performance (2016). $<$ http://www.didaskalia.net/reviews/2002_10_02_01. html>. Accessed 20 August 2020.

15. Murphy, Paula. Staging Histories in Marina Carr's Midlands Plays. Irish University Review, 2006. Print.

16. Novillo-Corvalán, Patricia. "The Theatre of Marina Carr: A Latin American Reading, Interview, and Translation." Literature, Art and Culture (2009): 145.

17. Parrott, Jennifer. "Ghostly Faces and Liminal Spaces: Landscape, Gender, and Identity in The Plays Of Marina Carr" Diss. University of Southern Illinois (Carbondale), 2010.

18. Randolph, Jody Allen. "The Shadow Side of Modern Ireland: Marina Carr's Midlands Tragedies." 2012. World Literature Today . <http://www.jstor.com>. Accessed 12 Septamber 2020.

19. Roche, Anthony. "Woman on the Threshold: J.M. Synge's The Shadow of the Glen, Teresa Deevy's Katie Roche and Marina Carr's The Mai." The Theatre of Marina Carr: 'Before Rules Was Made. Ed. Cathy Leeney and Anna McMullan. Dublin: Carysfort, 2003. 17-42.

20. Sihra, Melissa. "Nature Noble or Ignoble: Woman, Family, and Home in the Theatre of Marina Carr." Hungarian Journal of English and American Studies (HJEAS) 11.2 (2005): 133- 
مجلة وادي النيل للاراسات والبحوث الإنسانية والاجتماعية والتربوية (مجلة علمية محكمة)

(ISSN : 2536 - 9555)

147. <http://www.jstor.org/stable/41274324>. Accessed 28 October 2020.

21. Trotter, Mary. "A New Sense of Place: Irish Theatre since the 1990s." Modern Irish Theatre (2008): 176-194.

22. Turner, Victor. From Ritual to Theatre: The Human Seriousness of Play. New York: PAJ Publications, 1982.

23. Wallace, Clare. "A Crossroads between Worlds': Marina Carr and the Use of Tragedy." Litteraria Pragensia 10.20 (2000): 76-89. $<$ http://litterariapragensia.ff.cuni.cz/front.issue/detail/41>. Accessed 12 May 2020.

24. ---. "Authentic Reproductions: Marina Carr and Inevitable." The Theatre of Marina Carr: 'Before Rules Was Made. Ed. Cathy Leeney and Anna McMullan. Dublin: Carysfort, 2003. 43-64. 